\title{
Acidic Characterization of Copper Oxide and Niobium Pentoxide Supported on Silica-Alumina
}

\author{
Fillipe A. C. Garcia Valdeilson S. Braga • \\ Júnia C. M. Silva $\cdot$ José A. Dias · Sílvia C. L. Dias • \\ Jorge L. B. Davo
}

Received: 15 February 2007/ Accepted: 4 July 2007/Published online: 25 July 2007

(C) Springer Science+Business Media, LLC 2007

\begin{abstract}
Copper oxide and niobium pentoxide were supported on silica-alumina with $2,5,10,15$ and 25 mass\% loadings and 1:1 mass ratio of $\mathrm{CuO}: \mathrm{Nb}_{2} \mathrm{O}_{5}$. XRD and BET measurements confirmed that monolayer coverage is reached with loadings between 5-10 mass\% $\left(\sim 308 \mathrm{~m}^{2} \mathrm{~g}^{-1}\right)$. The DRIFTS spectra of pyridine adsorbed catalysts showed bands associated with Brönsted, Lewis and a combination of both acidic sites. Thermal analysis and liquid phase microcalorimetry provided the parameters for the best catalyst (10 mass\%), which has the highest number of acidic sites $\left(0.38 \mathrm{mmol} \mathrm{g}^{-1}\right)$ and enthalpies of interaction with pyridine for Brönsted and Lewis sites $\left(\Delta \mathrm{H}_{1}=-107.5\right.$ and $\Delta \mathrm{H}_{2}=-64.4 \mathrm{~kJ} \mathrm{~mol}^{-1}$, respectively $)$.
\end{abstract}

Keywords Copper oxide - Niobium pentoxide . Liquid phase microcalorimetry $\cdot$ Acidic characterization . Supported catalyst

F. A. C. Garcia · J. C. M. Silva · J. A. Dias $(\bowtie)$.

S. C. L. Dias $(\bowtie)$

Laboratório de Catálise, Instituto de Química, Universidade de Brasília, caixa postal 4478, Brasília, DF 70904-970, Brazil e-mail: jdias@unb.br

URL: http://www.unb.br/iq/labpesq/qi/labcatalise.htm

\section{S. Braga}

Instituto de Ciências Ambientais e Desenvolvimento Sustentável (ICADS), Universidade Federal da Bahia (UFBA), Rua Professor José Seabra S/N, Barreiras, BA 47805-100, Brazil

J. L. B. Davo

Technology Center CBMM-Companhia Brasileira de Metalurgia e Mineração, Córrego da Mata, s/n, Araxa, MG 38183-903, Brazil

\section{Introduction}

Copper has increasingly been used in the composition of a variety of catalysts, particularly in areas concerning applications in environmental processes [1-3]. Supported copper oxide is one the most promising catalytic materials for different pollutant abatement reactions [4-6]. In order to achieve high activity and selectivity, it is very important to obtain well dispersed oxide particles over the support [7]. Many studies have pointed out that the most active $\mathrm{CuO}$ phases are obtained in acidic supports and the dispersion is driven by the precursor addition method [1, 4].

Supported niobium pentoxide is one of the most studied oxides [8-10], largely because of its high acidity, activity and selectivity, despite the hydrophilic character of $\mathrm{Nb}_{2} \mathrm{O}_{5}$, which generally deactivates most catalysts. This water tolerant property makes such catalysts as an option for reactions in which water is implicated [11]. There are several recent reviews that discuss various applications of these catalytic materials, as well as the different roles that niobium assumes in each case $[9,12,13]$.

New catalytic materials containing copper oxide and niobium pentoxide supported on silica-alumina $(\mathrm{CuO} /$ $\mathrm{Nb}_{2} \mathrm{O}_{5} / \mathrm{SiO}_{2}-\mathrm{Al}_{2} \mathrm{O}_{3}$ ) have recently been characterized under distinct preparation conditions, oxide loadings (including sub-monolayer, monolayer and above-monolayer coverage) and calcination temperatures [14]. A strong influence was observed for the $\mathrm{CuO}$ over $\mathrm{Nb}_{2} \mathrm{O}_{5}$ crystallites, according to preparation method [10,14]. The most promising materials contained a $1: 1$ oxide ratio $\left(\mathrm{CuO}: \mathrm{Nb}_{2} \mathrm{O}_{5}\right)$, were prepared by simultaneous impregnation, and calcined at $300{ }^{\circ} \mathrm{C}$. It was determined the surface species composition as isolated $\mathrm{CuO}_{x}$ and/or $\mathrm{Nb}_{2} \mathrm{O}_{x}$ as well as polymerized $\mathrm{Nb}_{2} \mathrm{O}_{x}$ at lower coverage (2-5 mass\%); whereas at higher 
coverage (10-25 mass\%) crystalline $\mathrm{CuO}$ and amorphous $\mathrm{Nb}_{2} \mathrm{O}_{5}$ were observed [14].

Although the redox properties of these catalysts were tested by diesel soot oxidation of particulates, the acidic properties were not characterized. It is well known that solid acidity plays an important role in the activity of many catalysts [15]. Thus, this work addresses the acidic characterization of copper oxide and niobium pentoxide supported on silica-alumina $\left(\mathrm{CuO} / \mathrm{Nb}_{2} \mathrm{O}_{5} / \mathrm{SiO}_{2}-\mathrm{Al}_{2} \mathrm{O}_{3}\right)$ with a 1:1 $\left(\mathrm{CuO}: \mathrm{Nb}_{2} \mathrm{O}_{5}\right)$ ratio prepared by simultaneous impregnation. Since these catalysts have been well studied regarding their structural characterization [14], only $\mathrm{X}$-ray powder diffraction (XRD) was used for this purpose, as well as specific surface area measurements (BET). The acidic characterization was done by liquid phase microcalorimetry, diffuse reflectance infrared spectroscopy with Fourier transform (DRIFTS), and thermal analysis (TG/DTG/DTA) of the materials after pyridine adsorption.

\section{Experimental}

\subsection{Preparation of $\mathrm{CuO} / \mathrm{Nb}_{2} \mathrm{O}_{5} / \mathrm{SiO}_{2}-\mathrm{Al}_{2} \mathrm{O}_{3}$ Materials}

The catalysts were prepared by the impregnation method. The metal precursors, $\mathrm{Cu}\left(\mathrm{NO}_{3}\right)_{2} \cdot 3 \mathrm{H}_{2} \mathrm{O}$ (VETEC, 99\%) and $\mathrm{NH}_{4}\left[\mathrm{NbO}\left(\mathrm{C}_{2} \mathrm{O}_{4}\right)_{2}\left(\mathrm{H}_{2} \mathrm{O}\right)_{2}\right] \cdot\left(\mathrm{H}_{2} \mathrm{O}\right)_{n} \quad(\mathrm{CBMM}$, 99\%), were added to a round-botton flask with silica-alumina [10] (Aldrich, 12 mass $\% \mathrm{Al}_{2} \mathrm{O}_{3}$ ) and water in order to obtain a 1:10 ratio (mass to volume) of catalyst to water. Silicaalumina was activated by calcination at $550{ }^{\circ} \mathrm{C}$ for $12 \mathrm{~h}$, in order to transform it from ammonium to protonated form. The amounts of copper and niobium oxides were 2, 5, 10, 15 and 25 mass\% in order to obtain sub-monolayer, monolayer and above monolayer coverage. Each slurry sample was maintained at $80{ }^{\circ} \mathrm{C}$ until all of the water evaporated. Next, the solid was removed, ground to finer particles, placed in a vacuum oven at $120^{\circ} \mathrm{C}$ for $24 \mathrm{~h}$ and stored for further treatment.

\subsection{Thermal Treatment and Surface Area Measurements}

Previous studies performed in our laboratory and calorimetric experiments showed that the most acidic solids were produced after calcinations at $300{ }^{\circ} \mathrm{C}$. Thus, the catalysts were calcined at $300{ }^{\circ} \mathrm{C}$ for $6 \mathrm{~h}$ in a muffle furnace (EDG3PS-EDG Company) under static air conditions in porcelain crucibles, at a heating rate of $14{ }^{\circ} \mathrm{C} \mathrm{min}{ }^{-1}$. The specific surface area measurements of the calcined catalysts were determined by nitrogen adsorption at $77 \mathrm{~K}$ using the BET method in a Quantachrome apparatus (NOVA $1200 \mathrm{e}-$ Quantachrome Instruments). Before analysis, the samples were outgassed for $3 \mathrm{~h}$ in $\mathrm{N}_{2}$ at $300{ }^{\circ} \mathrm{C}$.

\subsection{X-ray Diffraction Measurements}

X-ray powder diffraction data were obtained with a Rigaku $\mathrm{D} / \mathrm{Max}-2 \mathrm{~A} / \mathrm{C}$ instrument with $\mathrm{Cu}-\mathrm{K} \alpha$ radiation of $1.5418 \AA(40 \mathrm{kV}$ and $20 \mathrm{~mA})$. A $2 \theta$ range from 2 to $90^{\circ}$ was scanned at $2^{\circ} \mathrm{min}^{-1}$. The crystalline and phase assignments were performed by comparing the PDF files from the International Centre for Diffraction Data (ICDD) included in the database of the software JADE 3.0 for XRD analysis.

\subsection{Acidic Characterization}

\subsubsection{Calorimetry}

The acidity of the solids was measured using acid-base calorimetric titrations of catalyst slurry with pyridine solution. These titrations were conducted in a modified isoperibol calorimeter (ISC Model 4300-Calorimetry Sciences Corporation) for heterogeneous reactions.

Before the titration, the catalysts were calcined in a glass reactor at $300{ }^{\circ} \mathrm{C}$ for $6 \mathrm{~h}$ under vacuum. The reactor was cooled to room temperature, opened in a nitrogen inert glove box and the solids were then stored in vials. The slurry was prepared through the transfer of $0.500 \mathrm{~g}$ of the catalyst from the vial to a Dewar calorimetric cell and adding $50 \mathrm{~mL}$ of anhydrous cyclohexane. This operation was conducted inside a glove box with nitrogen atmosphere. The Dewar was placed into the calorimeter in which a $5 \mathrm{~mL}$ calibrated syringe (Hamilton) with $0.1019 \mathrm{~mol} \mathrm{~L}^{-1}$ solution of pyridine in cyclohexane had been installed and equilibrated with a thermostatic bath at $26.0000{ }^{\circ} \mathrm{C}$. The system, Dewar-thermostatic bath-syringe, was equilibrated again at least for $30 \mathrm{~min}$ before starting the titration. Each point of the titration curve was obtained after addition of $0.05 \mathrm{~mL}$ of the titrant, and the system was equilibrated after each heat evolved for about $3 \mathrm{~min}$.

The calorimetric curves were analyzed using the ISC Analyze software provided by the calorimeter manufacturer. The software calculates the calorimeter heat capacity using a calibration curve made after each titration, and, using this value, the heat after each titrant addition. The heat of dilution between cyclohexane and pyridine solution was measured and considered negligible, in agreement with previous work [16]. Each titration was repeated twice with good reproducibility. 


\subsubsection{Spectroscopic Analysis}

DRIFTS spectra were acquired on a Bruker Equinox 55 spectrometer equipped with a Harrick diffuse reflectance accessory (The Praying Mantis ${ }^{\text {TM }}$ ) and a DTGS detector. All registered spectra were obtained with 256 scans and resolution of $4 \mathrm{~cm}^{-1}$. The spectra were baseline corrected and smoothed using polynomial functions. The calcined catalysts were placed in glass vessels where $2 \mathrm{~mL}$ of a $0.1019 \mathrm{~mol} \mathrm{~L}^{-1}$ solution of pyridine in cyclohexane were added. These vessels were left in an exhaust chamber at room temperature for $24 \mathrm{~h}$ to remove physically adsorbed species. The spectra were acquired as absorbance against an alignment mirror.

\subsubsection{Thermal Analysis (TG-DTA)}

The desorption analysis of the catalysts after pyridine adsorption was made using TG and DTA data obtained in a simultaneous TG-DSC model SDT 2960 from TA Instruments, with scan rate of $10{ }^{\circ} \mathrm{C} \mathrm{min}^{-1}$, from room temperature up to $900{ }^{\circ} \mathrm{C}$ under helium $(99.999 \%)$ flow of $100 \mathrm{~mL} \mathrm{~min}^{-1}$. Thermogravimetric curves where analyzed using the Universal Analysis (version 3.1E) software provided by Texas Instruments.

The number of Brönsted and Lewis acid sites was determined by quantitative analysis of TG/DTG curves of the catalysts after pyridine adsorption. First, it was determined the mass losses associated with water and pyridine desorption from the acid sites. Each mass loss, related to the desorption of pyridine from a given acid site, was normalized and converted in order to express the number of milimoles of pyridine adsorbed on such site per gram of anhydrous catalyst, using Eq. (1):

$n=\frac{\mathrm{m}_{\mathrm{py}}-\mathrm{m}_{\mathrm{cat}}}{\left(\mathrm{m}_{\mathrm{ini}}-\mathrm{m}_{\mathrm{w}}\right) \mathrm{MM}_{\mathrm{py}}}$

where, $\mathrm{m}_{\mathrm{py}}$ is the pyridine mass loss; $\mathrm{m}_{\mathrm{cat}}$ is the catalyst weight loss in the absence of pyridine, $\mathrm{m}_{\text {ini }}$ is the initial mass of the catalyst; $m_{w}$ is the mass loss of water and $\mathrm{MM}_{\mathrm{py}}$ is pyridine molar mass.

\section{Results and Discussion}

\subsection{Textural and Structural Characterization}

Silica-alumina decreased in specific surface area from ammoniacal $\left(475 \mathrm{~m}^{2} \mathrm{~g}^{-1}\right)$ to protonic form $\left(437 \mathrm{~m}^{2} \mathrm{~g}^{-1}\right)$. This is because of the dehydroxylation followed by sintering that occurs after thermal activation of this support.
Table 1 BET surface area of $\mathrm{CuO} / \mathrm{Nb}_{2} \mathrm{O}_{5} / \mathrm{SiO}_{2}-\mathrm{Al}_{2} \mathrm{O}_{3}$ with different oxide loadings

\begin{tabular}{ll}
\hline $\mathrm{CuO}(\mathrm{mass} \%)$ & $\begin{array}{l}\text { Surface area } \\
\left(\mathrm{m}^{2} \mathrm{~g}^{-1}\right)\end{array}$ \\
\hline $0^{\mathrm{a}}$ & 437.00 \\
2 & 345.2 \\
5 & 307.7 \\
10 & 313.6 \\
15 & 253.6 \\
25 & 166.7 \\
\hline
\end{tabular}

${ }^{a}$ Pure silica-alumina in the protonic form.

The results of surface area measurements of the catalysts are shown in Table 1. A general decrease in surface area with an increase in $\mathrm{CuO}$ and $\mathrm{Nb}_{2} \mathrm{O}_{5}$ loadings was observed, except for the 5 and 10 mass\% samples. The increase in oxide loading from 5 to $10 \mathrm{wt} \%$ did not obey this general trend because they are probably very close to the monolayer coverage. Thus, the increase in oxide loadings leads to the formation of small and well dispersed species over a monolayer support, which compensates the loss in surface area necessary to obtain the monolayer coverage.

The general behavior observed was expected since, once the oxide species cover the support, they form aggregates and may form mixed oxide species, which have lower surface areas [14]. Although the catalyst with 25 mass\% loading showed the lowest specific surface area of all catalysts prepared, it has a surface area considerably higher than the ones observed for other copper containing catalysts [17, 18], and for the pure metal oxides [19].

The XRD results of $\mathrm{CuO} / \mathrm{Nb}_{2} \mathrm{O}_{5} / \mathrm{SiO}_{2}-\mathrm{Al}_{2} \mathrm{O}_{3}$ after calcination at $300{ }^{\circ} \mathrm{C}$ are shown in Fig. 1 . The catalyst with 2 mass\% exhibited an amorphous pattern characteristic of the silica-alumina support. The catalyst with 5 mass\% exhibits

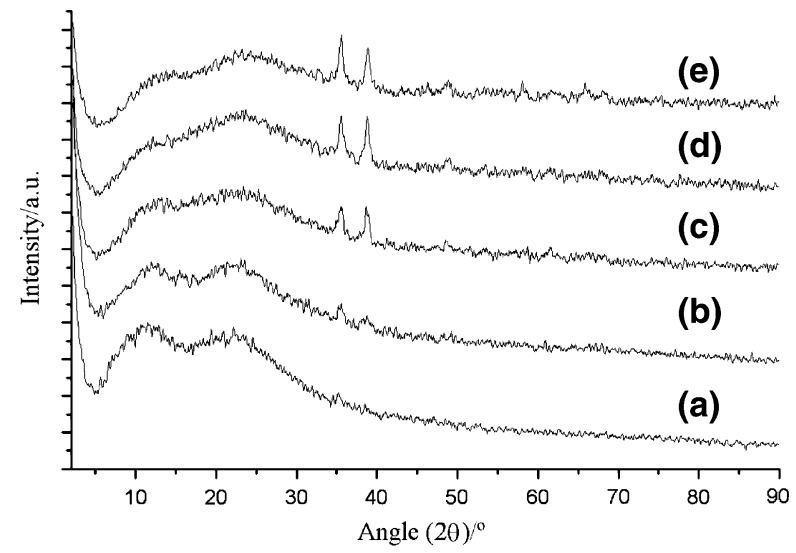

Fig. $1 \mathrm{XRD}$ patterns of $\mathrm{CuO} / \mathrm{Nb}_{2} \mathrm{O}_{5} / \mathrm{SiO}_{2}-\mathrm{Al}_{2} \mathrm{O}_{3}$ with: 2 (a), 5 (b), $10(\mathbf{c}), 15$ (d) and 25 (e) mass\% loadings after calcination at $300{ }^{\circ} \mathrm{C}$ for $6 \mathrm{~h}$ 
weak shoulders probably related to small $\mathrm{CuO}$ nanoparticles, which could also be present in the sample with 2 mass \%, as reported in the literature [20]. In addition, the catalysts with higher oxide loadings (10,15 and 25 mass\%) showed intense peaks at $2 \theta \cong 35.5$ and $38.7^{\circ}$ characteristic of $\mathrm{CuO}$ (PDF 05-0661) and no peaks associated with niobium pentoxide were observed, confirming that this oxide is amorphous at this calcination temperature [10]. These results suggest that the oxide loading necessary to obtain monolayer coverage of the protonic silica-alumina $\left(\sim 437 \mathrm{~m}^{2} \mathrm{~g}^{-1}\right)$ is between 5 and 10 mass\%, since the reflections associated with bulk $\mathrm{CuO}$ are only observed with loadings at or above 10 mass $\%$. The monolayer loading and the presence of amorphous $\mathrm{Nb}_{2} \mathrm{O}_{5}$ at $300{ }^{\circ} \mathrm{C}$ are in agreement with surface area results and previous studies reported in the literature [10,14].

\subsection{Spectroscopic and Thermal Analysis}

The DRIFTS spectra of the catalysts after pyridine adsorption presented absorptions at 1,549, 1,492 and $1,449 \mathrm{~cm}^{-1}$ (Fig. 2). The band at $1,549 \mathrm{~cm}^{-1}$ is associated with pyridine coordinated with $\mathrm{O}-\mathrm{H}$ terminal bonds or in hydrogen bonding that indicates the presence of Brönsted acid sites. The band at $1,449 \mathrm{~cm}^{-1}$ is due to pyridine adsorbed in Lewis acid sites (e.g., $\mathrm{Nb}=\mathrm{O}, \mathrm{Nb}-\mathrm{O}$ and/or $\mathrm{Cu}-\mathrm{O}$ ), with a contribution from the $\mathrm{O}-\mathrm{H}$ terminal bonds [21]; whereas the band at $1,492 \mathrm{~cm}^{-1}$ is associated with a combination of both acid sites.

It was also observed that the intensity of the band at $1,549 \mathrm{~cm}^{-1}$ decreased, while the intensity of the band at $1,449 \mathrm{~cm}^{-1}$ increased, with higher loadings of copper and niobium oxide. This observation presents further evidence that the oxides connect to the $\mathrm{O}-\mathrm{H}$ terminal bonds neutralizing the Brönsted acid sites, while increasing the number of Lewis acid sites. In other words, the impreg-

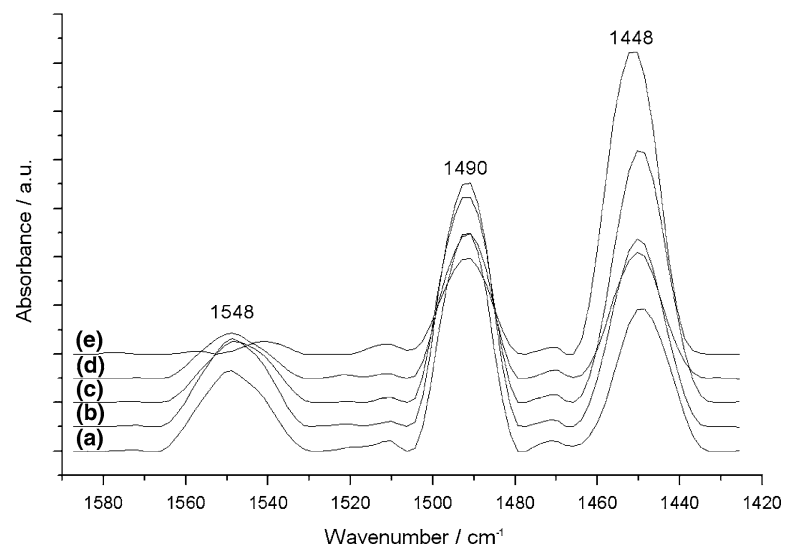

Fig. 2 DRIFTS spectra of $\mathrm{CuO} / \mathrm{Nb}_{2} \mathrm{O}_{5} / \mathrm{SiO}_{2}-\mathrm{Al}_{2} \mathrm{O}_{3}$ with 2 (a), 5 (b), $10(\mathbf{c}), 15$ (d) and 25 (e) mass\% loadings after pyridine adsorption nation of copper and niobium oxides exchanges the stronger Brönsted sites for weaker Lewis acidic sites [22].

The quantitative analysis of the DRIFTS spectra of all catalysts was made by the normalization of the spectra and the integration of the bands associated with contributions of each acid site separately $\left(1,549\right.$ and $\left.1,449 \mathrm{~cm}^{-1}\right)$. The ratio between Lewis and Brönsted peak areas represents a quantitative parameter to evaluate the effect of the amount of the oxides in the material acidity. The calculated ratios (Lewis/Brönsted) are shown in Table 2, which confirms the higher Lewis/Brönsted ratios for the materials with higher oxide loadings. This behavior suggests that the oxides bond to the silanol terminal groups, which is in agreement with other studies reported in the literature [14, 22] Table 3.

The only exception to this behavior was observed for the catalyst containing 15 mass\% loading, which exhibited a lower Lewis/Brönsted ratio than did the sample with 10 mass\%. This result may be explained by the fact that the sample with 10 mass\% is slightly over the experimental monolayer, which implies that an increase in copper and niobium oxide loadings may favor the formation of mixed oxides phases $[14,22]$ instead of neutralizing the remaining hydroxyl surface groups.

Figure 3 displays the DTG curves of the catalysts after pyridine adsorption. The samples containing 2 and 5 mass\% (Fig. 3a-b) show three mass losses at about 350, 450 and $600{ }^{\circ} \mathrm{C}$. These losses are associated with desorption of pyridine bonded to both Lewis and Brönsted acid sites, respectively. These assignments were based on the fact that there are two low temperature mass losses and only one high temperature loss, which are associated with the weaker and the stronger acid sites, respectively, because the stronger acid sites desorb pyridine at higher temperatures than the weaker ones.

The material with 10 mass\% (Fig. 3c) showed only the two low temperature mass losses $\left(330\right.$ and $450{ }^{\circ} \mathrm{C}$ ), which are associated with the Lewis acid sites. The absence of the third mass loss occurs due to the proximity of the experimental monolayer and the small amount of hydroxyl groups remaining on the support [14]. Another factor is that those remaining hydroxyl groups could be weakened or shielded by the presence of copper and niobium species near them, contributing to the desorption of pyridine at room temperature or completely preventing the adsorption on these sites. These results are consistent with calorimetric analysis (vide next section).

The catalysts containing 15 and 25 mass\% (Fig. 3d-e) also show two mass losses at $\cong 300$ and $800{ }^{\circ} \mathrm{C}$. The first one is related to pyridine desorption from both Lewis acid sites. The oxides exhibited similar behavior on these materials because their oxide loading is above the experimental monolayer, which favors the approximation of the bulk oxides as well as the formation of mixed oxide phases. 
Table 2 Results from the quantitative analysis of the DRIFTS spectra and TG-DTG curves of $\mathrm{CuO} / \mathrm{Nb}_{2} \mathrm{O}_{5} / \mathrm{SiO}_{2}-\mathrm{Al}_{2} \mathrm{O}_{3}$ using pyridine as a probe molecule

\begin{tabular}{|c|c|c|c|c|}
\hline $\mathrm{CuO}$ (mass\%) & $\begin{array}{l}\text { Lewis/Brönsted } \\
\text { ratio }^{\text {a }}\end{array}$ & $\begin{array}{l}\text { Lewis sites } \\
\left(\mathrm{mmol} \mathrm{g}^{-1}\right)\end{array}$ & $\begin{array}{l}\text { Brönsted sites } \\
\left(\mathrm{mmol} \mathrm{g}^{-1}\right)\end{array}$ & $\begin{array}{l}\text { Total acid sites } \\
\left(\mathrm{mmol} \mathrm{g}^{-1}\right)\end{array}$ \\
\hline 2 & 1.20 & 0.12 & 0.09 & 0.21 \\
\hline 5 & 1.42 & 0.29 & 0.06 & 0.35 \\
\hline 10 & 2.83 & 0.38 & - & 0.38 \\
\hline 15 & 2.02 & 0.11 & - & 0.11 \\
\hline 25 & 31.09 & 0.32 & - & 0.32 \\
\hline
\end{tabular}

a The Lewis/Brönsted ratio was calculated with the areas of the bands in 1,449 $\mathrm{cm}^{-1}$ (Lewis) and 1,549 $\mathrm{cm}^{-1}$ (Brönsted)

Table 3 Results for the average entalpies of Brönsted $\left(\Delta \mathrm{H}_{1}\right)$ and Lewis $\left(\Delta \mathrm{H}_{2}\right)$ acidic sites of each catalyst interacting with pyridine

\begin{tabular}{lcl}
\hline $\mathrm{CuO}(\mathrm{mass} \%)$ & $-\Delta \mathrm{H}_{1}\left(\mathrm{~kJ} \mathrm{~mol}^{-1}\right)$ & $-\Delta \mathrm{H}_{2}\left(\mathrm{~kJ} \mathrm{~mol}^{-1}\right)$ \\
\hline 2 & 100.4 & 64.5 \\
5 & 97.9 & 64.8 \\
10 & 107.5 & 64.5 \\
15 & 90.8 & 39.3 \\
25 & 73.2 & 60.3 \\
\hline
\end{tabular}

The presence of these phases has a leveling effect on the strength of the Lewis sites weakening them. The leveling effect can be demonstrated by the shift on the desorption temperature from $350{ }^{\circ} \mathrm{C}$, for the catalysts with lower loadings, to $300{ }^{\circ} \mathrm{C}$, for the catalysts with higher loading. The second mass loss is probably associated with the formation of copper niobate with contributions from the reduction of $\mathrm{CuO}[14,22,23]$. The formation of copper niobate has been previously assigned for the materials calcined at $800{ }^{\circ} \mathrm{C} / 6 \mathrm{~h}[14,23]$.

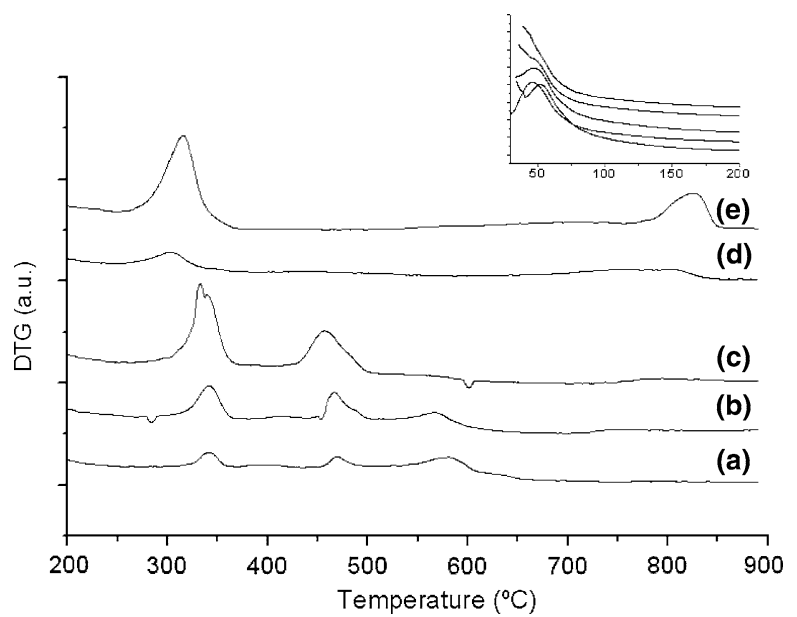

Fig. 3 DTG curves of the $\mathrm{CuO} / \mathrm{Nb}_{2} \mathrm{O}_{5} / \mathrm{SiO}_{2}-\mathrm{Al}_{2} \mathrm{O}_{3}$ with: 2 (a), 5 (b), $10(\mathbf{c}), 15$ (d) and 25 (e) mass\% loadings, after pyridine adsorption
In addition, the mass loss observed at $800{ }^{\circ} \mathrm{C}$ in the catalyst with 25 mass $\%$ loading, could also be observed as a broad peak near the baseline in the DTG curves of the catalysts with lower oxide loadings. In those cases the mass loss is not so important, due to its small intensity and because it is related to the reduction of $\mathrm{CuO}$ forming $\mathrm{Cu}_{2} \mathrm{O}$ [23].

The quantitative analysis of the TG-DTG curves was performed by normalizing the mass losses in order to obtain the weight of pyridine per gram of dry catalyst and the number of moles desorbed from each type of acid site. The mass loss was then converted to milimoles of pyridine, which allowed the total number of acid sites to be calculated. The normalization is mandatory to make sure that the degree of hydration and sample mass are the same among the catalysts.

The quantitative results from TG-DTG analysis are presented in Table 2 and agree with the interpretation of DRIFTS spectra, since a decrease of Brönsted sites and a concomitant increase of Lewis sites with the increase of sample loading was observed. In addition, the total number of acid sites increased with sample loadings because of the higher amount of surface metal oxides. The decrease in the total number of acid sites in the sample with 15 mass\% is probably due to the formation of mixed oxide phases, which leads to the formation of a smaller amount of Lewis acid sites without changing the number of Brönsted acid sites.

Another interesting result obtained from the quantitative analysis of the TG-DTG curves was that the catalyst with 25 mass\% has less acid sites than the one with 10 mass $\%$. That result can also be explained by the formation of mixed oxide phases, which decreases the number of Lewis acid sites. Another factor is that the sample with 25 mass\% loading is well above monolayer, which implies that there is only a small amount of Brönsted acid sites. These results do not contradict the analysis of the DRIFTS spectra, since the latter provides only a Lewis/ Brönsted ratio, which does not directly relate to the total number of acid sites. 


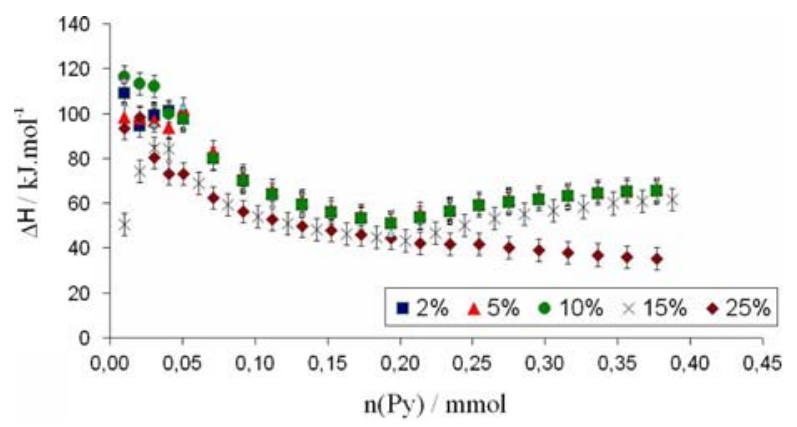

Fig. 4 Calorimetric curves of $\mathrm{CuO} / \mathrm{Nb}_{2} \mathrm{O}_{5} / \mathrm{SiO}_{2}-\mathrm{Al}_{2} \mathrm{O}_{3}$ interaction with pyridine in cyclohexane. The error bars were set at $\pm 5 \mathrm{~kJ} \mathrm{~mol}^{-1}$

\subsection{Calorimetric Analysis}

The calorimetric titrations provide the heat evolved after pyridine addition, which relates directly to the interaction of that molecule with the Brönsted and Lewis acid sites present on the catalyst surface. The curve of the calculated enthalpy versus amount of pyridine added may be divided in three regions (Fig. 4): the first one accounts for the highest enthalpy of interaction releasing around $94 \mathrm{~kJ}$ $\mathrm{mol}^{-1}$ (average of the 5 samples), which occurs up to about $0.05 \mathrm{mmol}$ of pyridine added; the second region ranges from sites with enthalpy values from -80 to $-50 \mathrm{~kJ} \mathrm{~mol}^{-1}$, between 0.05 and $0.2 \mathrm{mmol}$ of base added; while the third region displays sites with an average enthalpy around $-58.7 \mathrm{~kJ} \mathrm{~mol}^{-1}$ after addition of $0.2 \mathrm{mmol}$ of pyridine.

The preferential reaction of pyridine is on the surface Brönsted acidic sites because of the higher strength and lower free energies of these sites. In the middle region there is a simultaneous interaction of the base with the remaining Brönsted as well as Lewis acid sites showing lower enthalpies than the pure Brönsted, but higher than pure Lewis (third region). The Lewis sites are weaker, but their amount increases with copper content, as explained above. Thus, they started reacting with pyridine before all Brönsted sites have been neutralized.

A similar behavior in all calorimetric curves was observed, yet the strength of the sites is dependent upon the loading of $\mathrm{CuO}$ and $\mathrm{Nb}_{2} \mathrm{O}_{5}$. The catalysts with 2 and 5 mass $\%$ showed similar average enthalpies $\left(\Delta \mathrm{H}_{1} \sim-99 \mathrm{~kJ} \mathrm{~mol}^{-1}\right)$; whereas the 10 mass\% sample is the most acidic $\left(\Delta \mathrm{H}_{1} \sim-107 \mathrm{~kJ} \mathrm{~mol}^{-1}\right)$. For the samples with higher loadings (15 and 25 mass $\%$ ), the heat released decreases. The decrease of the BET specific surface area probably makes the pyridine access more difficult because it facilitates the blockage of the porous due to larger agglomerates formed by increasing the oxides loading on the support.
The calorimetric results can be compared to TG-DTG data, since measured enthalpy and the number of sites are average values. Slurry microcalorimetric experiments are more sensitive than the TG-DTG technique being able to detect much lower concentrations of the strongest Brönsted sites [24, 25]. For the samples with 2 and 5 mass $\% \mathrm{CuO}$, the amount of the strongest sites is quite similar, considering the qualitative approximation obtained by the calorimetric method. However, the pyridine desorption from the Brönsted acid sites for the samples with loading higher than 5 mass\% could not be observed. These sites were probably averaged in the further peak of desorption $\left(450{ }^{\circ} \mathrm{C}\right)$ or were even not detected at all because of their low concentration (lower than $0.05 \mathrm{mmol} \mathrm{g}^{-1}$ of these sites). In addition, the samples with 15 and 25 mass $\% \mathrm{CuO}$ showed desorption at high temperature $\left(800{ }^{\circ} \mathrm{C}\right)$, which is associated mainly with the formation of $\mathrm{CuNbO}_{6}$ [14]. Thus, evaluation of the Brönsted acidic contribution for that DTG peak is unreliable.

It is also interesting to compare the strongest acidic sites of these materials with some other related solid acids. Protonic silica-alumina catalyst calcined at $300{ }^{\circ} \mathrm{C}$ exhibited a reaction enthalpy with pyridine of $\sim-92.1 \mathrm{~kJ}$ $\mathrm{mol}^{-1}$; whereas pure $\mathrm{Nb}_{2} \mathrm{O}_{5}$ (also calcined at $300{ }^{\circ} \mathrm{C}$ ) showed an average enthalpy of about $-71.1 \mathrm{~kJ} \mathrm{~mol}^{-1}$ [26]. The enthalpy values for the strongest sites present on the materials containing 5, 10, 15 and 25 mass $\%$ of $\mathrm{Nb}_{2} \mathrm{O}_{5}$ supported on silica-alumina $\left(\mathrm{Nb}_{2} \mathrm{O}_{5} / \mathrm{SiO}_{2}-\mathrm{Al}_{2} \mathrm{O}_{3}\right)$ were $-104.6 ;-112.9 ;-96.2$; and $-83.7 \mathrm{~kJ} \mathrm{~mol}^{-1}$, respectively [26]. This trend allows for two important conclusions: first, that the addition of copper oxide decreases the acidity of the materials with only supported niobium pentoxide; second, that the most acidic material is still the one containing 10 mass $\%$ of both oxides. Thus, the calorimetric results confirm DRIFTS measurements in which it was observed that the addition of $\mathrm{CuO}$ did not saturate all the available hydroxyls of the silica-alumina support [14]. Instead, there is a partial neutralization of hydroxyl groups of supported niobia by copper precursor. For $\mathrm{Nb}_{2} \mathrm{O}_{5} / \mathrm{SiO}_{2}$ $\mathrm{Al}_{2} \mathrm{O}_{3}$ catalysts, the monolayer was experimentally obtained at 10-15 mass\% of niobia [10]; whereas for $\mathrm{CuO} /$ $\mathrm{Nb}_{2} \mathrm{O}_{5} / \mathrm{SiO}_{2}-\mathrm{Al}_{2} \mathrm{O}_{3}$, the monolayer was estimated to be between 5 and 10 mass\% of $\mathrm{CuO}$ [14] (both values obtained by XRD and Raman studies). It was also reported in the literature that niobium pentoxide supported on zirconia has the most acidity, and hence better activity, for materials with approximately $80 \%$ coverage [27]. Thus, it seems that the best materials develop high acidity for concentrations close to the monolayer and those are the most active materials for acid catalysis reactions. This fact has been observed by esterification of acetic acid with different alcohols using $\mathrm{Nb}_{2} \mathrm{O}_{5} / \mathrm{SiO}_{2}-\mathrm{Al}_{2} \mathrm{O}_{3}$ as catalysts [26]. 


\section{Conclusions}

The catalytic materials based on $\mathrm{CuO} / \mathrm{Nb}_{2} \mathrm{O}_{5} / \mathrm{SiO}_{2}-\mathrm{Al}_{2} \mathrm{O}_{3}$ were prepared with 1:1 $\left(\mathrm{CuO}: \mathrm{Nb}_{2} \mathrm{O}_{5}\right)$ by the impregnation method. Their structural characterization with XRD and BET indicated that the monolayer coverage is obtained with $\mathrm{CuO}$ loading between 5 and 10 mass $\%$. The DRIFTS spectra, after pyridine adsorption, showed the presence of both Brönsted and Lewis acid sites in all prepared catalysts and that both copper and niobium precursors interact with silica-alumina through hydroxyl terminal groups. A decrease in Brönsted and an increase in Lewis acidic sites as the oxide loading increase were observed. The acidic behavior of the prepared catalysts was characterized regarding the total number of acid sites, the approximated number of each kind, and the enthalpy of reaction with pyridine. Considering the potential application of these materials, the catalyst containing 10 mass\% is the most promising, since it has the highest number of acid sites $\left(0.38 \mathrm{mmol} \mathrm{g}^{-1}\right)$, as well as the highest enthalpies of reaction with pyridine for both Brönsted and Lewis sites $\left(\Delta \mathrm{H}_{1}=-107.5\right.$ and $\Delta \mathrm{H}_{2}=-64.4 \mathrm{~kJ} \mathrm{~mol}^{-1}$, respectively $)$.

Acknowledgments We acknowledge $\mathrm{CNPq}$ for scholarships to doctorate and undergraduate students and the financial support provided by UnB-IQ (FUNPE), FINATEC, FINEP/CTPetro, FAPDF/ SCDT/CNPq, CAPES, and CNPq. The authors would like to thank Prof. Edi Mendes Guimarães from Laboratório de Difração de Raios$\mathrm{X}(\mathrm{IG} / \mathrm{UnB})$ for XRD measurements and CBMM for the niobium reagents.

\section{References}

1. Gervasini A, Manzoli M, Marthra G, Ponti A, Ravasio N, Sordelli L, Zaccheria F (2006) J Phys Chem B 110:7851

2. Yahiro H, Iwamoto M (2001) Appl Catal A 222:163

3. Yamada K, Pophal C, Segawa K (1998) Microporous Mesoporous Mater 21:549
4. Bennici S, Gervasini A (2006) Appl Catal B 62:336

5. Geus JW, Dillen AJV (2001) In: Janssen FJJG, van Santen RA (eds) Environmental catalysis. Imperial College Press, London

6. Weissermel K, Arpe H-J (1997) Industrial organic chemistry, 3rd edn. VCH-A Wiley company, Weinheim

7. Sagar GV, Rao PVR, Srikanth CS, Chary KVR (2006) J Phys Chem B 110:13881

8. Wachs IE (2005) Catal Today 100:79

9. Nowak I, Ziolek M (1999) Chem Rev 99:3603

10. Braga VS, Dias JA, Dias SCL, Macedo JL (2005) Chem Mater 17:690

11. Okuhara T (2002) Chem Rev 102:3641

12. Ziolek M (2003) Catal Today $78: 47$

13. Tanabe K (2003) Catal Today $78: 65$

14. Braga VS, Garcia FAC, Dias JA, Dias SCL (2007) J Catal 247:68

15. Tanabe K, Misono M, Ono Y, Hattori H (1989) Studies in surface science and catalysis, vol 51. Elsevier, Tokyo

16. Caliman E, Dias JA, Dias SCL, Prado AGS (2205) Catal Today 107-108:816

17. Tabakova T, Idakiev V, Papavasiliou J, Avgouropoulos G, Ioannides T (2007) Catal Comm 8:101

18. El-Shobaky GA, El-Khouly SM, Ghozza AM, Mohamed GM (2006) Appl Catal A 302:296

19. van Doorn J, Varloud J, Mériaudeau P, Perricón V (1992) Appl Catal B 1:117

20. Benici S, Gervasini A, Ravasio N, Zaccheria F (2003) J Phys Chem B 107

21. Mohamed IZ, Muhammad AH, Fakhrya A, Al-Sagher (2001) Coll Surf A 190:61

22. Braga VS, Garcia FAC, Dias JA, Dias SCL, Barros ICL (2005) Anais do $13^{\circ}$ Congresso Brasileiro de Catálise 2:1311

23. Hatekeyama T, Liu Z (1999) Handbook of thermal analysis. John Wiley and Sons, New York

24. Drago RS, Dias JA, Maier TO (1997) J Am Chem Soc 119:7702

25. Drago RS, Dias SC, Torrealba M, de Lima L (1997) J Am Chem Soc 119:4444

26. Braga VS, Barros ICL Garcia FAC, Dias SCL, Dias JA (2007) "Esterification of acetic acid with alcohols using supported niobium pentoxide on silica-alumina catalysts", accepted for publication. Catal Today

27. Onfroy T, Clet G, Bukallah SB, Hercules DM, Houalla M (2003) Catal Lett 89:15 